\title{
傾斜リブ付き高アスペクト比矩形通路の熱伝達特性*
}

\author{
岡 村隆 成*1, 古閑昭 紀 $^{* 2}, 川$ 岸裕 之*2
}

\section{Heat Transfer in High Aspect Ratio Rectangular Passage with Skewed Ribs}

\author{
Takanari OKAMURA*3, Akinori KOGA and Hiroyuki KAWAGISHI \\ ${ }^{* 3}$ Hachinohe Institute of Engineering, Dept. of Energy Engineering, \\ 88-1 Obiraki, Myo, Hachinohe, Aomori, 031-8501 Japan
}

\begin{abstract}
The heat transfer characteristics and flow behavior in a rectangular passage with two opposite $45^{\circ}$ skewed ribs for turbine rotor blade have been investigated for Reynolds numbers from 7800 to 19000 . In this blade, the spanwise coolant passage at the trailing edge region whose thickness is very thin is chosen, so the channel aspect ratio (=width/height of channel) is extremely high, 4.76. Therefore the heat transfer experiment in the high aspect ratio cooling channel was performed using thermochromic liquid crystal and thermocouples. Furthermore the calculation of flow and heat transfer was carried out using CFD analysis code to understand the heat transfer experimental results. The enhanced heat transfer coefficients on the smooth side wall at rib leading end were the same level as those on the rib roughened walls.
\end{abstract}

Key Words: Heat Transfer, Thermochromic Liquid Crystal, Numerical Analysis, Turbine Blade, Gas Turbine

\section{1. 緒言}

WE-NET(World Energy Network) 計画は国家プ ロジェクトの一つとして，エネルギーと環境問題を解 決することを目的とした水素の製造から利用技術に至 る開発計画である。この中に，水素・酸素燃焼の $1700^{\circ} \mathrm{C}$ 級タービン発電システムの開発がある。この 発電システムは $\mathrm{CO}_{2}$ や $\mathrm{NO}_{x}$ の排出がまったくないゼ ロエミッションで, かつ発電端熱効率が $60 \%$ (燃料の 高位発熱量基準) 以上の高効率のプラントを目標とし ている。このシステムのキー技術であるタービン冷却 翼の研究開発計画が示されている(1). 本論文では冷却 翼の中で特に回転体として厳しい高温環境下で作動す る初段タービン動翼の冷却通路内の熱伝達特性に関し て述べる。

$$
\text { タービン翼の冷却方法は翼メタル温度が設計寿命を }
$$
満足するレベルに維持できるように永年研究が行われ てきた，冷却技術の課題はガスタービンの性能を改善 するために高い内部熱伝達率を達成すると同時に，冷

* 原稿受付 1999 年 7 月 22 日.

*1 正員, 八戸工業大学工学部エネルギー工学科(⓪31-8501 八 戸市妙大開 88-1) [元：(株) 東芝].

*2 正員, (株) 東芝電力システム社電力・産業システム技術開発 センター(罗230-0045 横浜市鶴見区末広町 2-4).

E-mail : okamura@hi-tech.ac.jp
却媒体流量を最少化することである，最新の夕ービン 動翼では，冷却通路内の熱伝達率を促進するために， 壁面に連続するリブが取付けられている，通路の幅と 高さの比であるアスペクト比, 通路水力直径に対する リブ高さ，リブ取付角，リブ高さとピッチ比，そして リブ形状などが熱伝達特性に影響する。これらは実験 あるいは解析によって, 多くの研究者によって調べら れている(2) (13). これらの中で, Han 他の研究(4) が本 論文に近い内容であり, 矩形通路におけるリブ取付角 と通路アスペクト比を変化させた場合の熱伝達率への 影響が調べられている.アスペクト比は 2 から 4 まで の範囲を，そしてリブ取付角は $90,60 ４ 5^{\circ}$ そして $30^{\circ}$ まで変化させている，通路内のリブ取付面とリブのな い側壁の熱伝達率を熱電対を使って計測している。し かしながら，相対する側壁の熱伝達率を区分して議論 されていない.

本論文では，アスペクト比が 4.76 で, 通路水力直径 に対するリブ高さが 0.173 の矩形通路を取扱ってお り，これらの值は上記論文の範囲を超えている。この ような従来にない形状の冷却通路をタービン動翼に適 用するためには，リブ取付面と同時に側壁の熱伝達率 の改善と高精度の見積もりが重要である. それは側壁 の一方が翼後縁に対応しているためである。 
この研究の目的は高アスペクト比の傾斜リブ付き矩 形通路内の側壁も含めた壁面の局所および平均熱伝達 率を明らかにすることである，熱伝達率はレイノルズ 数が 7800 から 19000 の範囲で液晶と熱電対を使って 計測されている。 さらに，通路内の流れの様子と熱伝 達特性を理解するために, CFD 解析コードを使って 計算を行った。試験で得られた熱伝達率および圧力損 失の結果と, 計算值との比較の結果を示す。また, 計 算で得られた通路内の流れの状態と熱伝達率分布の結 果から，リブによって誘起される二次流れがリブ付き 面と側壁の熱伝達特性に与える影響について述べる。

\section{2. 初段タービン動翼}

初段タービン動翼は高温蒸気雾囲気下で作動するた め翼材料，コーティングそして冷却法の面で大きな特 徵を有している。まず，翼材料として，クリープ寿命， 熱サイクル疲労そしてじん性などの面で, 従来の Ni 基一般鋳造合金に比べて優れた特性を備えた単結晶合 金が採用されている，そして熱流束を低減して翼のメ タル温度上昇を阻止するために低熱伝導率の物性を有 する $\mathrm{ZrO}_{2}$ 系の遮熱コーティング(TBC：Thermal Barrier Coating)功適用されている。タービン翼に供 給された冷却蒸気をすべて回収する方式は，プラント 性能の面から望ましいが，翼の前縁や後縁部のように 高い熱負荷を受ける領域で翼基材と TBC 表面の温度 を許容レベルに維持することは困難である，したがっ て，ここでは回収式を基本として，一部フィルム冷却 のような吹出しを併用する方式，すなわち，ハイブリ ッド方式を採用している。

初段静翼抢よび動翼の縮小モデル試験翼を水素・酸 素燃焼の高温蒸気風洞に組み込んで冷却特性等の翼列 試験を実施する。試験翼の寸法は出力 $500 \mathrm{MW}$ 級の 実機タービン翼の約 $1 / 2$ である.試験動翼の仕様を表 1 に示す. 翼コードは $36.6 \mathrm{~mm}$ で, 翼表面には実機 と同じ $\mathrm{ZrO}_{2} \bullet 8 \% \mathrm{Y}_{2} \mathrm{O}_{3}$ の厚さ $0.15 \mathrm{~mm}$ の $\mathrm{TBC}$ が施 エされている. 試験翼の外観と冷却構造を図 1 に示

Table 1 Specifications of the first stage turbine rotor blade

\begin{tabular}{|c|c|}
\hline Items & Specification \\
\hline Blade height [mm] & 40 \\
\hline Chord length $[\mathrm{mm}]$ & 36.6 \\
\hline $\begin{array}{l}\text { Thermal barrier coating } \\
\text { Blade material }\end{array}$ & $\begin{array}{c}2 \mathrm{ZO}_{2}-8 \times \mathrm{Y}_{2} \mathrm{O}_{3} \\
\text { Single crystal super alloy } \mathrm{CMSX}-4\end{array}$ \\
\hline Cooling scheme & $\begin{array}{l}\text { Hybrid type(combination of closed } \\
\text { circuit and open circuit including film } \\
\text { cooling at leading edge and blowout from } \\
\text { trailing edge tip) }\end{array}$ \\
\hline
\end{tabular}

す. 翼前縁部にはインピンジメント冷却とシャワーへ ッド冷却の組合せを採用しており，翼中央部にはサー ペンタイン冷却通路を適用している。現有の空気冷却 ガスタービンでは, タービン翼の後緑部は通常, 主流 ガス流れに沿った冷却通路で構成されて, 冷却空気は 後緑吹出しされる。しかしながら，この方式は多量の 冷却媒体を必要とするため, プラント性能の面から吹 出し量を最少化するために, この部位は半径方向のリ ブ付き冷却通路を採用している。冷却流量の約 $60 \%$ が回収されて燃焼器入口に戻され，残りが主流がス中 に吹出される。後縁部は肉厚が薄いため, 冷却通路は 偏平になり，通路の幅 $W$ と高さ $H$ の比で定義される アスペクト比 $A_{s}(=W / H)$ 嵪くなる。後縁は曲率半 径が小さいために, 外面の周長に対して内面の周長割 合が小さくなり，この部位のメタル温度を許容温度以 下に維持するためには，内面の熱伝達率を大幅に促進 させる必要がある。

\section{3. 熱伝達試験}

\section{$3 \cdot 1$ 試験装置 傾斜リブ付き矩形通路内の熱伝}
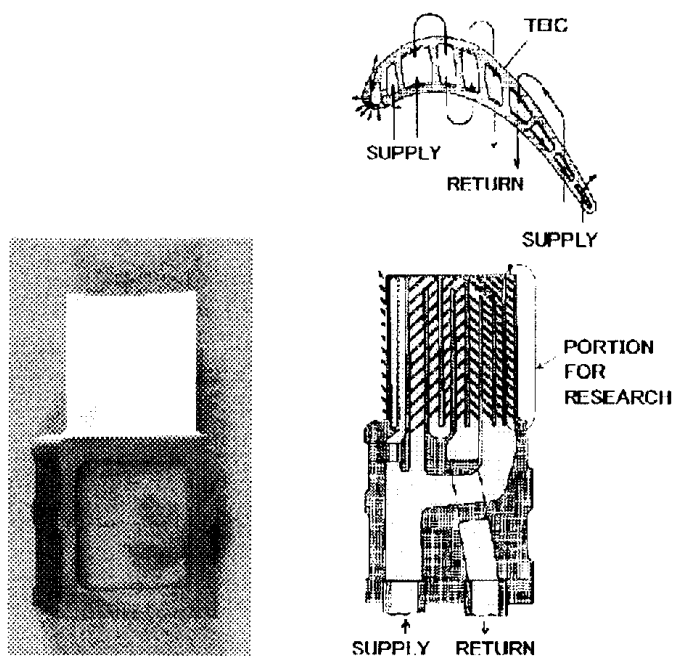

Fig. 1 Appearance and cooling structure of the first stage turbine rotor blade for high temperature wind tunnel test

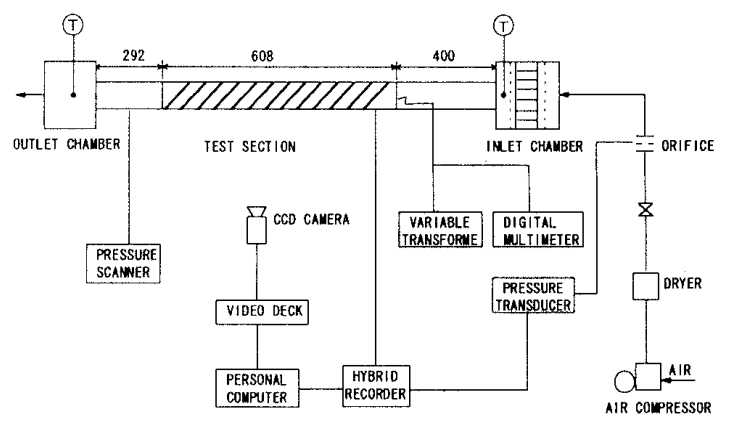

Fig. 2 Experimental apparatus and measuring system of heat transfer coefficient 
達率および王力損失の計測を行うための試験装置の全 体系統を図 2 に示す，試験供試体にはドライヤと流量 計を通じて電動機駆動の送風機によって空気が供給さ れる，供試体の入口部には整流格子が設けられ，また 入口，出口部の温度計測を行うために熱電対が設置さ れている，試験対象のリブが取付けられているダクト の長さは $608 \mathrm{~mm}$ で，その前後の平滑ダクトの長さは それぞれ $400 \mathrm{~mm}$ と $292 \mathrm{~mm}$ で，これらのダクトで静 圧が計測される。

入口部を除いて供試体はすべてアクリルで作られて いる. CCD カメラ(東芝製 3 CCD カラーカメラ IK$\mathrm{T} 40)$ が供試体の $530 \mathrm{~mm}$ 後方に設置されて, 高周波 ランプが $45^{\circ}$ の角度で供試体を照射している。図 3 に 供試体の概念図を，表 2 にその仕様を示す．供試体の 寸法は図 1 に示す試験動翼の後縁部に設けられる冷却 通路の 15 倍の大きさである. ダクトのリブ取付面の 幅 $W$ は $50 \mathrm{~mm}$ で, 高さ $H$ は $10.5 \mathrm{~mm}$ であり, 水力 直径 $D$ は $17.4 \mathrm{~mm}$ である.ダクトの 4 面は $10 \mathrm{~mm}$ 厚さのアクリル製で，リブは正方形断面のアクリル製 であり，ダクト 2 面に 16 本/面のリブが $45^{\circ}$ 傾斜で千 鳥配列で等ピッチで取付けられている。リブピッチ $p$ は $36 \mathrm{~mm}$ で, リブ高さ $e$ は $3 \mathrm{~mm}$, リブピッチと高さ の比 ple は 12 , 水力直径に対するリブ高さの比 $e / D$ は 0.173 である.このリブ高さの比 $e / D$ は，試験動翼 のリブ形状が精密鋳造の制限からこれ以上小さくでき ないために，通常採用されている值よりも大きい值が 取られている。

液晶による計測の構成を図 4 に示す。液晶は壁面の 内面に塗布されており，直径 $0.05 \mathrm{~mm}$ の熱電対がそ の上に取付けられて,ブラックインキが塗布されてい る.その上に厚さ $0.05 \mathrm{~mm}$ の両面テープを使って電

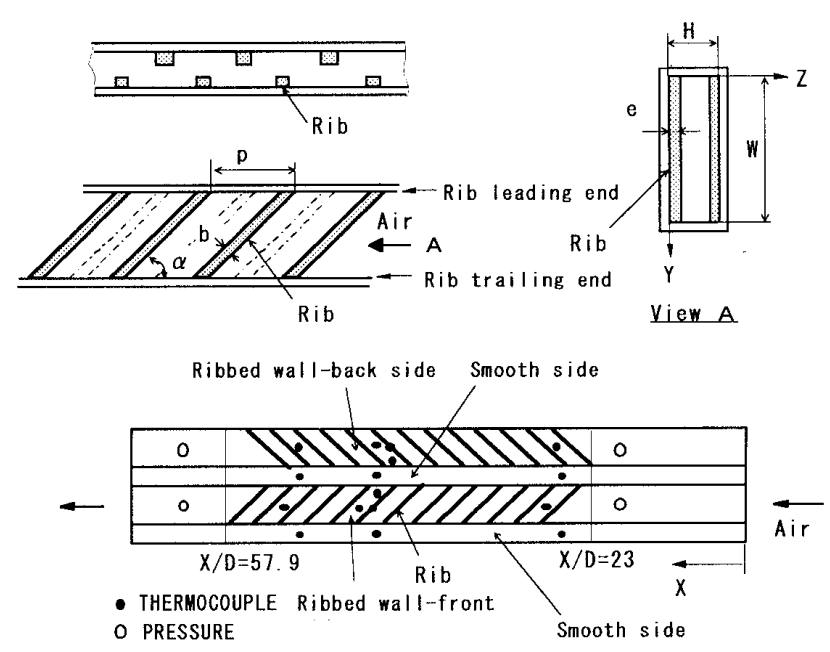

Fig. 3 Schematic drawing of test section
気ヒータで覆われており，さらにその上にリブが取付 けられている.電気七ー夕は $0.025 \mathrm{~mm}$ 厚さの $\mathrm{Ni}^{-}$ Cr 板で，リブが取付けられているダクトの4面に張 られている。電気抵抗を増加させるために，リブ付き 面の七一夕は下流側の端部で連続させて中心線上で 2 分割されている。それによってヒータの抵抗はリブ取 付面で $2.75 \Omega$ ，側壁面で $3.42 \Omega$ である。

$3 \cdot 2$ データ計測図 2 と図 3 に熱伝達率の計測 システムを示す。ヒータの温度は 18 本の熱電対で計 測され，静圧は 4 点で計測される．流量は入口部の流 量計で計測される，壁面の熱伝達率は計測された表面 温度分布, 熱流束と空気温度から求められる，表面温

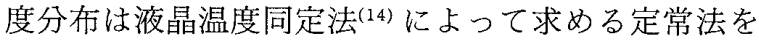
採用している。熱流束は各ヒー夕の電压と抵抗から求 めることができる。それぞれのヒー夕は個別に電圧を 調整することができるので，液晶のカラー表示に適し た温度範囲が選定できる，しかしながら，カラー表示 できる温度範囲が限られているため，供試体のすべて の領域をカバーできるように，ヒータの電圧は 4 段階 に分割して計測を行っている，リブ付き面での熱伝達 率計測はリブ間の壁面に有効であるが，リブは熱伝導 率の低いアクリル製のため, リブ自身の熱伝達率は計 測されていない，供試体の計測位置での空気温度は計 測された入口および出口の空気温度から演算される。 電気ヒータの供試体への入熱は外気への放熱があるた め，熱伝達率の計算を行ううえで，この点が考慮され ている。供試体内の圧力損失は供試体出入口の側壁で 計測した値から演算されている。

液晶で提示されるカラーと温度との関係を求めるた めの構成カーブを得るために，試験前に供試体に空気

Table 2 Specifications of test section

\begin{tabular}{|l|c|c|c|c|c|c|}
\hline \multirow{2}{*}{ Channel } & $W(\mathrm{~mm})$ & $H(\mathrm{~mm})$ & $\begin{array}{c}\text { As } \\
(=W / \mathrm{H})\end{array}$ & \multirow{2}{*}{$D(\mathrm{~mm})$} & \multicolumn{2}{|c|}{} \\
\cline { 2 - 7 } & 50 & 105 & 4.76 & 17.4 & \multicolumn{2}{|c|}{} \\
\hline \multirow{2}{*}{ Rib } & $e(\mathrm{~mm})$ & $\mathrm{b}(\mathrm{mm})$ & $0(\mathrm{~mm})$ & $\alpha(\mathrm{deg})$ & $\mathrm{e} / \mathrm{D}$ & $\mathrm{p} / \mathrm{e}$ \\
\cline { 2 - 7 } & 3 & 3 & 36 & 45 & 0.173 & 12 \\
\hline
\end{tabular}

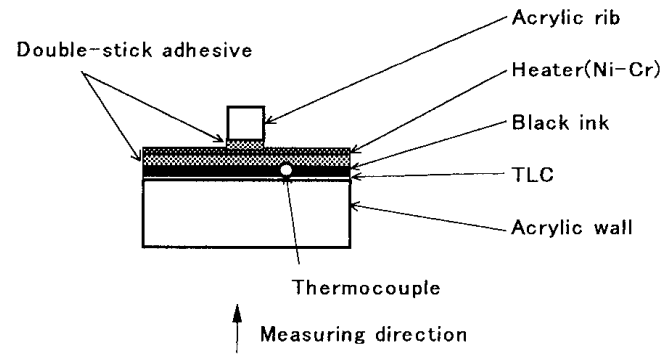

Fig. 4 Thermochromic liquid crystals measuring structure 
を流さない状態で, 供試体をできるだけ均一で安定し た温度になるまでヒータで加熱した後, CCDカメラ による液晶力ラーと熱電対による液晶温度の計測を行 い，これらの関係を求めた。図 5 に 3 原色 $\mathrm{R}, \mathrm{G}, \mathrm{B}$ の 構成カーブを示す. $38^{\circ} \mathrm{C}$ か $48^{\circ} \mathrm{C}$ 温度範囲が測定 可能域である、試験の不確かさを ASME 試験コード （1986）によって求めた結果, 熱伝達率は土8\%, 圧力損 失は $\pm 12 \%$ である。

$3 \cdot 3$ 試験結果 まず，リブが取付けられている ダクトの入口から出口までの流れ方向の熱伝達率に関 して，リブ間の壁面のほぼ中央に設置された熱電対で 計測されたヌッセルト数 $N u(=h D / \lambda)$ の分布を図 6 に 示す。ここで, $h$ は熱伝達率, $D$ は夕゙クトの水力直径, $\lambda$ は空気の熱伝導率である。この值は平滑面に対する 次の Dittus-Boelterの関係式で得られる熱伝達率の 値で基準化されている.

$$
N u_{0}=0.023 \operatorname{Re}^{0.8} \mathrm{Pr}^{0.4}
$$

ここで, レイノルズ数 $\operatorname{Re}(=U \cdot X / \nu)$ は, 通路内平均 流速 $U$, 図 3 に示寸試験供試体入口からの距離 $X$, そして動粘性係数レによって定義される。Prはプラ ントル数である．空気の物性值は位㯰 $X$ にお污る温 度の関数として求められる. 入口から第 1 番めのリブ

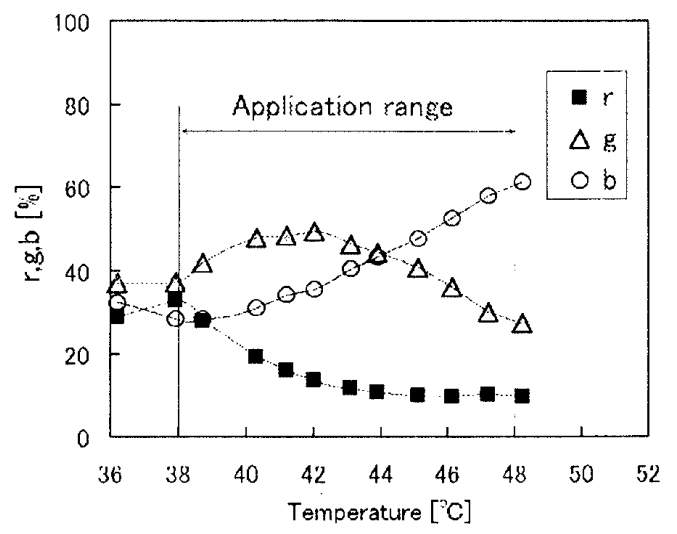

Fig. 5 Calibration curve for thermochromic liquid crystals

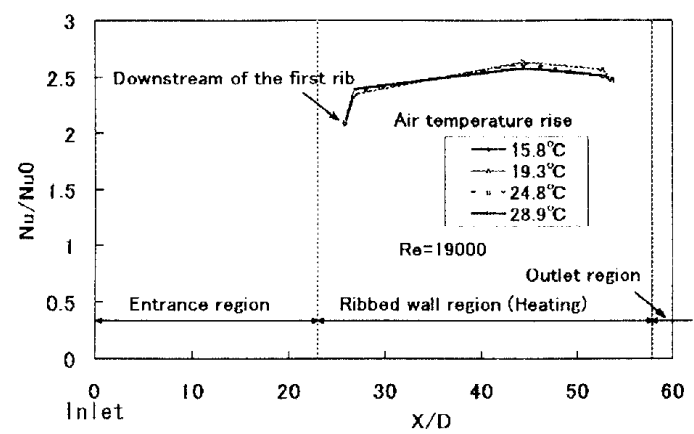

Fig. 6 Local heat transfer ratio of ribbed wall measured by thermocouple whose locations are same relative to ribs
の下流でのヌッセルト数は下流側の值よりも多少低い が, 第 2 番めのリブ下流での值はそれ以降の下流側で の值とほとんど同じレベルにある。このことから，高 アスペクト比の通路内の流れは急速に発達した流れの 状態になることがわかる. 図 7 にレイノルズ数が 19000 と 7800 でのリブ付き面の局所熱伝達率分布を 示す。計測範囲は $X / D$ が 42.2 から 48.7 の範囲であ る。熱伝達率はやはり，式（1）によって基準化されて いる.両レイノルズ数に対するヌッセルト数は同じよ うな分布を示している，熱伝達率はリブ間の中央壁面 で高く,この領域は後で述べる CFD 解析の結果から 見られるようにりブを超えてきたはく離流れの再付着 域と対応している。さらに詳しく見ると, 熱伝達率は リブ前縁端側領域 (Rib leading end side) で最も高く, 逆にリブ後縁端側 (Rib trailing end side)領域では低 い值を示している。一方，リブのない側壁面では，液 晶によって計測された温度分布に大きな変化が見られ なかったので, この面の熱伝達率の計測結果は熱電対
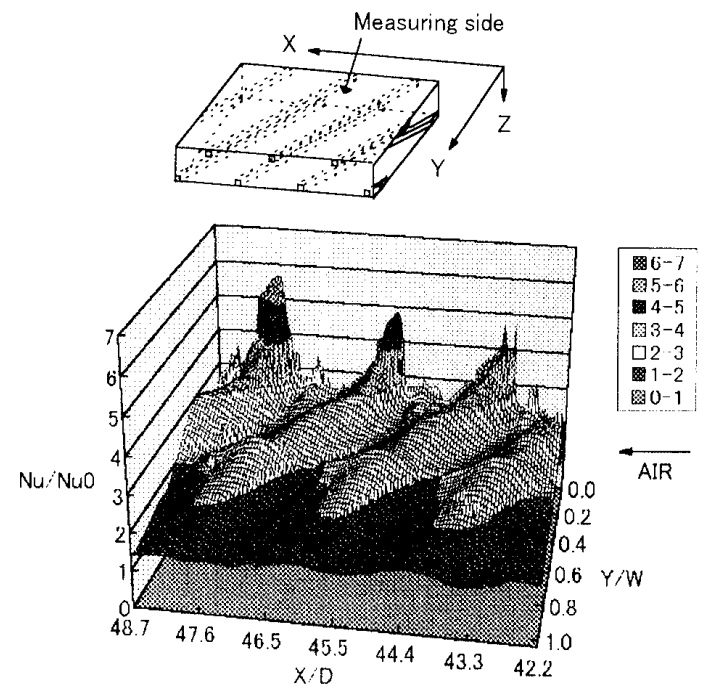

(a) $\operatorname{Re}=19000$

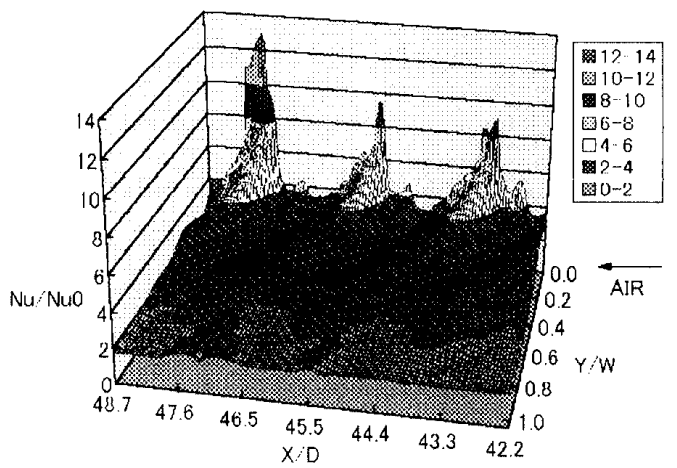

(b) $R e=7800$

Fig. 7 Distribution of heat transfer coefficient on ribbed wall 


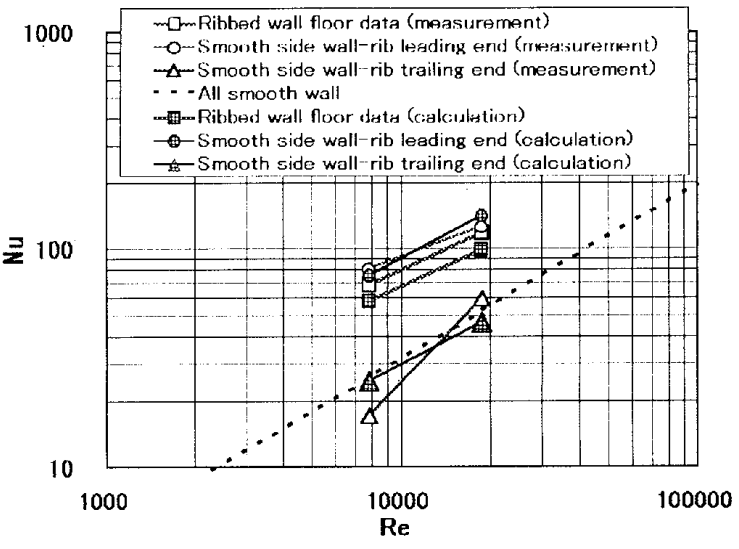

Fig. 8 Measurement and calculation of average heat transfer coefficient

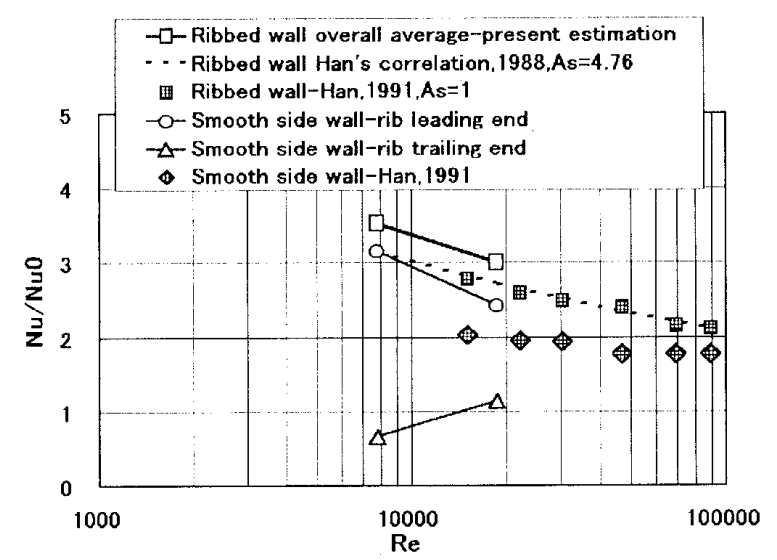

Fig. 9 Average Nusselt number ratio versus Reynolds number for the ribbed wall and smooth side walls

のみの計測值でまとめた，図 8 に平均ヌッセルト数と レイノルズ数との関係を示す.リブ取付面の熱伝達率 はりブを除いた壁面の平均値である。りブ前縁端側側 壁の熱伝達率はりブ付き面壁面の値よりも高くなって おり，一方，リブ後縁端側側壁の熱伝達率は平滑面の それとほぼ同じレベルにある。

次に，リブ付き面におけるリブも含めた全体平均熱 伝達率を推定する。リブ自身の熱伝達率は計測されて いないので,この部位の值は次のように推定した。 $\operatorname{Taslim}^{(10)}$ は，傾斜りブ付きダクトでリブ 3 面の平均 熱伝達率 $h_{\mathrm{rib}}$ とリブ間の壁面での值 $h_{\text {floor }}$ を計測して いる.これらの計測值を使って, 壁面に対するリブの 熱伝達率の比 $R h\left(=h_{\mathrm{r} 1 \mathrm{~b}} / h_{\mathrm{floor}}\right)$ を計算すると, 試験条 件で多少異なり，1.25あるいはもう少し高い値にな り，ここでは両者の通路のアスペクト比などのパラメ 一タの違いを考慮して，Rh=1.25を採用する。この 值からリブの熱伝達率がわかるので，リブ付き面の 1 ピッチ分の投影面積における全体平均熱伝達率は次式 によって求められる。

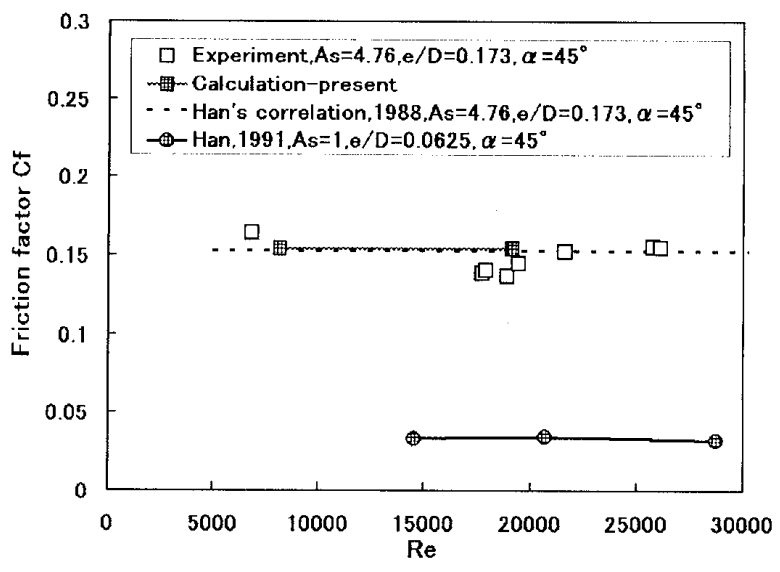

Fig. 10 Friction factor in ribbed channel versus Reynolds number

$$
h_{\text {overall }}=\left(h_{\text {floor }} A_{\text {floor }}+h_{\text {rib }} A_{\text {rib }}\right) / A_{p}
$$

ここで, $A_{\text {floor }}$ はリブ間壁面の面積, $A_{\text {rib }}$ はリブ 3 面 の面積, $A_{p}$ はリブ 1 ピッチ分の投影面積である. 図 9 に全体平均ヌッセルト数のレイノルズ数との関係を 示す.リブ付き面のヌッセルト数はレイノルズ数が 7800 から 19000 で, 3.0 から 3.5 の範囲にあり, この 值はHanの関係式あるいは計測值よりも多少大き い.この要因として, 本試験でのリブ高さ比 $e / D$ は Hanの関係式の適用範囲を超えており,リブ高さの 効果が大きく現れたものと推定される. Hanの試験 体は，壁面が銅で，リブが黄銅で作られており， $A_{s}=$ $1, e / D=0.0625, \alpha=45^{\circ}$ である. Han の側壁面の值は 2 面の平均值で示されて, おのおのに分割されていな い.この平均值では本計測值は Han の結果と同じレ ベルにある。

図 10 に摩擦係数とレイノルズ数との関係を示す。 摩擦係数はほぼ一定の值であり, Hanの関係式とよ く一致しているが, 試験結果に対しては大きな值とな っている。これは本試験の $e / D$ と $A_{s}$ が, $\operatorname{Han}$ の試験 条件よりも大きいことに依存していると考えられる。

\section{4. 熱流体解 析}

$4 \cdot 1$ 計算モデル＼cjkstart高アスペクト比の冷却通路を 模擬した試験通路内の流れと熱伝達の現象を理解する ために，三次元ナビエ・ストークス方程式を組み込ん だはん用解析コード STAR-CD Ver. 3.0. を使って内 部流れの数值計算を行った。この解析コードは数種の 解析法や乱流モデルが準備されており，ここでは二次 中心差分法と SIMPLE法を適用して, 壁法則と関連 付けた標準の $k-\varepsilon$ 乱流モデルを使用している. 表 3 に解析の境界条件を示す.ケース A とケース B は形 状は同じで，レイノルズ数がそれぞれ 19000 と 7800 
Table 3 Boundary conditions of analysis

\begin{tabular}{|c|c|c|c|c|c|}
\hline \multirow[b]{2}{*}{ Case } & \multicolumn{3}{|c|}{ Inlet conditions } & \multirow[b]{2}{*}{$\begin{array}{c}\text { Wall temp } \\
\text { (K) }\end{array}$} & \multirow[b]{2}{*}{$\operatorname{Re}$} \\
\hline & $\begin{array}{c}\text { Static press } \\
(\mathrm{MPa})\end{array}$ & $\begin{array}{c}\text { Total temp } \\
(\mathrm{K})\end{array}$ & $\begin{array}{c}\text { Velocity } \\
(\mathrm{m} / \mathrm{s})\end{array}$ & & \\
\hline A & 0.1018 & 282.7 & 15.02 & 303.2 & 19000 \\
\hline$B$ & 0.1018 & 282.7 & 6.38 & 303.2 & 7800 \\
\hline
\end{tabular}

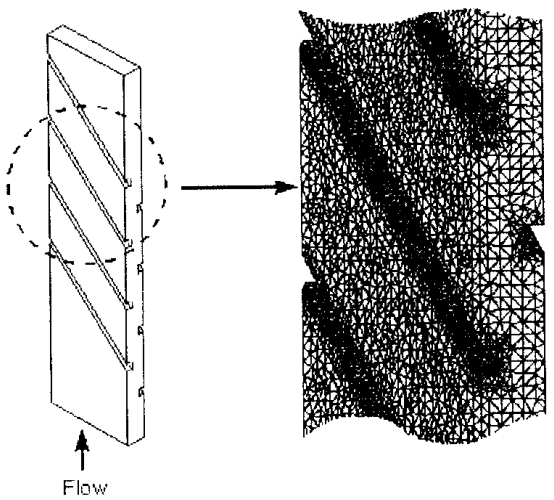

Fig. 11 Calculation grid

で，流体の状態量および物性值は試験条件と合せてあ る.入口の速度分布は一様で, 主流乱れ強さは $3 \%$ と している. 通路内の物性值は温度の関数としている。 図 11 に解析対象のリブ付き通路の格子図を示す。 格子を創製するために，非構造格子創製コード ICEM CFD-Tetra を使用した。このコードは CADの作成 形状にしたがって自動的に四面体要素で空間を満たし

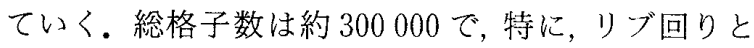
壁面近くは壁関数の適用性を考慮して，微細な格子寸 法としている. 無次元壁距離 $y^{+}$は 30 から 100 の範 囲を取るように推奨されており，ここでは，壁面近く で 30 程度の值になるようにしている. $45^{\circ}$ 傾斜りブ は相対する両面に取付けられて片側 4 本としている。 熱伝達率の試験結果と解析の結果からも入口から 2 本 目のリブで十分に発達した流れになっていることを確 認しており，この解析形状で十分安定した状態を得る ことができる．解析結果と試験結果を比較，検討する ために，解析結果はリブ本数が入口から第 3 本めと第 4 本めの間のデータを対象とする.

\section{$4 \cdot 2$ 試験と解析結果の比較}

（1） 熱伝達率と流れの様子 三次元の熱流体解 析の結果と試験で得られた熱伝達率および圧力損失に ついて比較を行う。図 12 にリブ付き面と側壁の全 4 面の熱伝達率分布の計算結果を示す。ケース $\mathrm{A}$ とケ ース B の結果はほとんど同じ傾向を示しているので, ケースAのレイノルズ数が 19000 の場合のみを示 す。リブ付き壁面は相対する面でほとんど同じ特性を 示している。リブ間の壁面中央部が高い熱伝達率を示

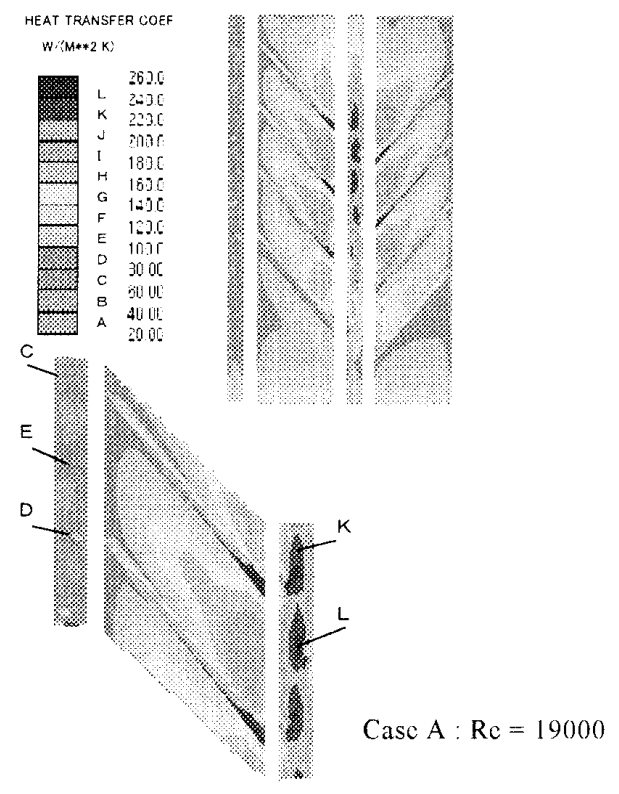

Fig. 12 Distribution of heat transfer coefficient in ribbed channel
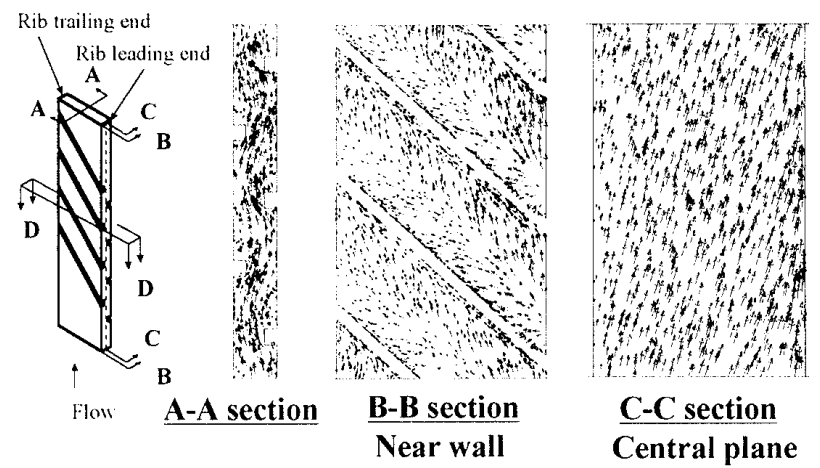

Case $A: R e=19000$

Fig. 13 Velocity vectors in cross sections of ribbed channel

しており，この中でも，リブ前縁端側の領域が最も高 く，逆にリブ後緣端側の領域で低い值を示している. 試験結果 (図 7 ) と計算結果 (図 12) の比較で, 両者は非 常によく似た分布を示している.リブ間の壁面で熱伝 達率が最も高い值と最も低い值との比は計算結果では 約 2.5 で, 試験では約 3.0 であり，両者はほほ同じレ ベルにある，そしてリブ面は概して高い值をもち，特 に, リブ前縁端側の領域が後縁端側の比べて高くなっ ている.

リブのない側壁において，双方の壁面はおのおの周 期的なパターンを示している。しかしながら，熱伝達 率はまったく異なった特性をもち，リブ前縁端側の側 壁は非常に高い値であるのに比べて，相対するリブ後 縁端側では極めて低い值である。この特性の違いはリ ブに誘起される二次流れが大きく影響していることが 
予想される。

図13に通路内の速度ベクトルを示す. A 断面にお いて, 主流はは行して進行している。これは水力直径 に対するリブ高さの比が大きいことと，リブが千鳥配 列されていることに起因している。流れはリブ下流で はく離流れとなり，リブ間の中央領域で再付着してい る. $\mathrm{B}$ 断面と $\mathrm{C}$ 断面の速度べクトルはリブの効果を よく表している. B 断面はりブ付き面の壁から 0.8 $\mathrm{mm}$ 離れた壁面近くの位置であり, リブで誘起される 二次流れによって引き起こされる流れのパターンが見 られる。リブの下流側ではく離域を形成しており，壁 面中央部には再付着域があり，そしてリブの上流域で リブに沿う平行な流れが見られる。また，壁面に近い 流れの速度はリブ前縁端側で速く、リブ後縁端側では 遅い。この流れの特徴は壁面の熱伝達率の分布と対応 している.C断面を見ると, 通路断面中央の主流流れ はリブ後縁端側からリブ前緑端側に向かっており, 流 れ方向は壁面近くの流れ方向と逆向きである.

この主流流れの温度は図 14 に示すように壁面近く の流れに比べて低いことがわかる．この冷たい主流流 れがリブ前縁端側の側壁に衝突することによってこ の側壁面の熱伝垟率が促進されるものと考えられる。 逆に, リブ後縁端側の側壁面では, 主流はこの面から 離れるように流れており,これによって熱伝達率が低 下する. Kiml ら (15) はアスペクト比が $2 て ゙, 60^{\circ}$ 傾斜 リブ付きの通路内の流れ観察をアルゴンレーザシート を使ってレイノルズ数が 10000 から 20000 の範囲で 実施している。計測はリブ付き壁面に近い領域から通 路中央まで行っており，図 13 と極めて類似した流れ のパターンを得ている。これら両者の結果はアスペク ト比が高い傾斜リブ付き通路内の流れの特性を示すも のである.試験結果と計算値の比較を図 8 亿示すよう
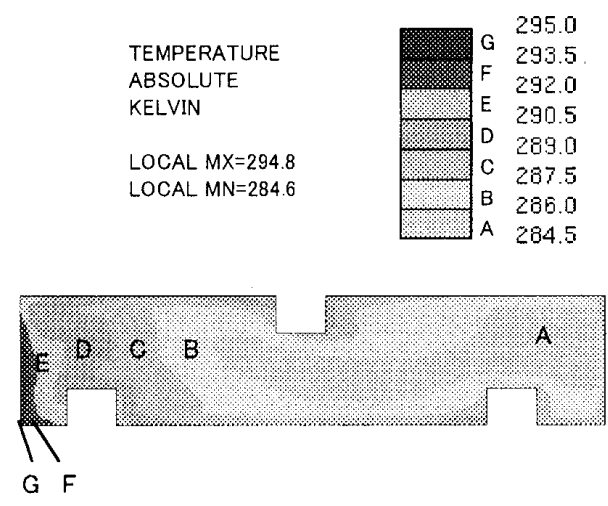

[D-D section] Case A : $\mathrm{Re}=19000$

Fig. 14 Temperature distribution in ribbed channel
に, 計算結果はリブ取付面とリブのない側壁の双方で 試験結果とよく一致している。

（2）リブの熱伝達率 リブ自身の熱伝達特性を 把握するために, 通路内の熱伝達率計算結果からりブ 3 面の平均熱伝達率とリブ間の壁面の平均熱伝達率の 比 $R_{h}$ を求めた。この值はレイノルズ数が 7800 と 19000 の双方で同じで, 1.14 であり, Taslimの試験 結果 ${ }^{(10)}$ から求めた 1.25 よりも少し低い值であるがほ ぼ同レベルであり,りブ面での熱伝達率は壁面に対し て高い值を取ることを確認した。

（3）摩擦係数 計算で求められたりブ 1 ピッチ 分の圧力損失加摩擦損失を求めた。その結果を図 10 に示すように計算結果は試験結果と非常によく一 致しておう, 平滑面通路に対して 24 倍高い值である.

リブ付き通路内の同様な解析が行われておりり(2)(16), 熱伝達率や圧力損失は乱流モデルや格子サイズに強く 影響を受けることが示されている。ここでは，リブ付 き通路の流れと熱伝達率の計算に $k-\varepsilon$ 乱流モデルと 特に壁面近傍で小さな格子サイズを採用することで， 計算值は試験結果とよく一致する結果が得られた。

\section{5. 結 論}

高アスペクト比の $45^{\circ}$ 傾斜リブ付き矩形通路内の熱 伝達率と圧損特性を試験と解析によって調べ, 次の結 論を得た。

（1）リブ付き面において, 全体平均ヌッセルト数 比はレイノルズ数が 7800 から 19000 の範囲で, 3.0 から 3.5 である.この值は同样傾斜リブ付きの正方形 通路内の発達した状態での熱伝達率と同じレベルであ る. 局所熱伝達率分布はりブ間の中央部の領域で高い 值を示し，特に，リブ前縁端側で最大值を取る.

（2）リブのない側壁面では, 平均ヌッセルト数は リブ前縁端側の側壁で高く, リブ付き壁面と同じレベ ルにある。この面の熱伝達率はりブによって誘起され る二次流れによって促進されている。一方，リブ後縁 端側の側壁の熱伝達率は平滑面の値と同じ低いレベル にある。このような両側壁の極端な特性の違いを生じ る機構を明らかにした。

（3）水力直径に対して高いリブ高さをもつ本通路 に打ける摩擦係数は 0.15 で, 平滑面通路に対して 24 倍高い。また, この值は試験範囲のレイノルズ数には 依存しない. 圧力損失の計算値は試験結果とよい一致 を示した。

（4）熱伝達率の計算結果は試験のレイノルズ数範 囲でリブ付き面と側壁の双方で, 試験結果とよく一致 している. 乱流モデルと格子サイズの選定によって, 
本研究で使用した解析コードは局所および平均熱伝達 率そして圧力損失を求めるうえで十分な精度を有し， また，流れの様子を把握するうえで有効である.

この研究は新エネルギー産業技術開発機構 (NEDO) から社団法人日本発電設備技術検査協会を 通して, WE-NET 計画の一部として委託されたもの であり，両機関に研究の支援に対して謝意を表する。

\section{文献}

(1) Mouri, K., Arai, N., Taniguchi, H. and Maekawa, H., Research and Development of Hydrogen Combustion Turbine and Very Hot Heat Exchanger in WE-NET Project, IJPGC'98 1(1998), 433-437.

(2) Bonhoff, B., Tomm, U. and Johnson, B. V., Heat Transfer Predictions for U-Shaped Coolant Channels with Skewed Ribs and with Smooth Walls, ASME Paper, 96-TA-7(1996).

(3) Dutta, S., Andrews, M. J. and Han, J. C., Prediction of Turbulent Flow and Heat Transfer in Rotating Square and Rectangular Smooth Channels, ASME Paper, 96GT-234 (1996).

(4) Han, J. C. and Park, J. S., Developing Heat Transfer in Rectangular Channels with Rib Turbulators, Int. J. Heat Mass Transf, 31-1(1988), 183-195.

(5) Han, J. C., Zhang, Y. M. and Lee, C. P., Augmented Heat Transfer in Square Channels with Parallel, Crossed, and V-Shaped Angled Ribs, ASME J. Heat Transf., 113(1991), 590-596.

(6) Han, J. C. and Zhang, Y. M., High Performance Heat Transfer Ducts with Parallel Broken and V-Shaped Broken Ribs, Int. J. Heat Mass Transf., 35-2(1992), 513-523.

(7) Mochizuki, S., Beier, M., Murata, A., Okamura, T. and Hashidate, Y., Detailed Measurement of Convective
Heat Transfer in Rotating Two-Pass Rib-Roughened Coolant Channels, ASME Paper, 96-TA-6 (1996).

(8) Shih, T. I-P., Lin, Y. -L., Stephens, M. A., Chyu. M. K. and Civinskas, K. C., Flow and Heat Transfer in a Ribbed U-Duct under Typical Engine Conditions, ASME Paper, 98-GT-213(1998).

(9) Taslim, M. E., Li, T. and Kercher, D. M., Experimental Heat Transfer and Friction in Channels Roughened with Angled, V-Shaped and Discrete Ribs on Two Opposite Walls, ASME Paper, 94-GT-163(1994).

(10) Taslim, M. E. and Lengkong, A., $45^{\circ}$ Staggered Rib Heat Transfer Coefficient Measurements in a Square Channel, ASME Paper, 96-TA-9(1996).

(11) Taslim, M. E. and Lengkong, A., $45^{\circ}$ Round-Corner Rib Heat Transfer Coefficient Measurements in a Square Channel, ASME Paper, 98-GT-176 (1998).

(12) Shine Fann, Wen-Yang and Nengli Zhang, Local Heat Transfer in a Rotating Serpentine Passage with RibRoughened Surface, Int. J. Heat Mass Transf., 372(1994), 217-228.

(13) Parsons, J.A., Han, J.C. and Zhang, Y., Effect of Model Orientation and Wall Heating Condition on Local Heat Transfer in a Rotating Two-Pass Square Channel with Rib Turbulators, Int. J. Heat Mass Transf., 38-7(1995), 1151-1159.

(14) Matsuda, H., Ikeda, K., Nakata, Y., Otomo, F., Suga, T. and Fukuyama, Y., A New Thermochromic Liquid Crystal Temperature Identification Technique Using Color Space Interpolations and its Application to Film Cooling Effectiveness Measurements, Proc, 2nd Pacific Symp., Flow Visualiz. Image Process., PF 053(1999).

(15) Kiml, R., Mochizuki, S. and Murata, A., Heat Transfer Distribution and Flow Behavior in a Rectangular RibRoughened Passage, Proc. GTSJ Proc., (1998), 189193.

(16) Abuaf, N. and Kercher, D. M., Heat Transfer and Turbulence in a Turbulated Blade Cooling Circuit. ASME Paper, 92-GT-187(1992). 